DOI https://doi.org/10.18551/rjoas.2018-09.65

\title{
SEAWEED ABILITY TOWARDS ORGANIC SUBSTANCE DECLINE IN TIGER SHRIMP (PANAEUS MONODON) CULTIVATION
}

\author{
Irawan Hery* \\ Coastal Resource Management, Faculty of Fisheries and Marine Science, \\ University of Diponegoro, Indonesia \\ Rejeki Sri, Purnomo Pujiono Wahyu \\ Aquaculture Department, Faculty of Fisheries and Marine Science, \\ University of Diponegoro, Indonesia \\ *E-mail: ihery.hi@gmail.com
}

\begin{abstract}
Objective of this study is to evaluate how effective seaweed is in reducing organic substance in semi-intensive tiger shrimp cultivation. This study used Sargassumsp, Gracilaria sp. and Caulerpa sp. seaweed which is spread $50 \mathrm{grams} / \mathrm{m}^{2}$. The tiger shrimp density is 30 shrimps $/ \mathrm{m}^{2}$. Each treatment is repeated three times for 68 days. The finding showed that the treatments had significant influence towards both organic substance and seaweed growth. However, the treatment did not have significant influence towards the tiger shrimp. The seaweed reduces percentage of the organic substance. The seaweed does not have any influence towards Panaeus monodon growth and biomass. Each treatment results in different seaweed growth and biomass. Caulerpa sp. has higher biomass and better growth level compared to Sargassum sp. and Gracilaria. Seaweed can reduce organic substance in the tiger shrimp cultivation and as the result, increase its productivity as well as income of tiger fish farmers.
\end{abstract}

\section{KEY WORDS}

Organic substance, quality of water, shrimp cultivation, Sargassumsp, Gracilaria sp., Caulerpa sp., Panaeus monodon.

Additional shrimp feed plays pivotal role in stimulating growth of the biota. However, there is some amount of shrimp feed that goes to waste either directly and indirectly. Shrimp feed that is not consumed is categorized as direct waste while one that is digested and excreted in the form of feces is called indirect waste. Shrimp feed is the main source of organic substance in shrimp farm ( $\mathrm{Li}$ and Boyd, 2016). Excessive organic substance in the water will produce toxic nitrite (NO2) and ammonia (NH3) (Wulandari, et.al, 2015). Seaweed has indirect influence towards growth and productivity of both shrimp farm and the environment as it can absorb nutrients and act as physical filter. Besides that, being a profitable commodity, seaweed may become an additional source of income for fish farmers (Buschmann, 1996; Neori, et.al, 1996; Chow, et.al, 2001; Hernandez, et.al, 2002; MartinezAragon, et.al, 2002; Msuya, et.al, 2006; Knovitvadhi, et.al, 2008, Chaitanawisuti, et.al, 2011). Objective of this study is to analyze ability of seaweed in decreasing decrease organic substance and how much influence seaweed has towards growth of tiger shrimp. This study involved three types of seaweed, namely Sargassum sp, Gracilaria sp and Caulerpa sp.

\section{MATERIALS AND METHODS OF RESEARCH}

This study lasted for 68 days between May and July in Tambak Bulusan village, Demak. The study used a $100 \mathrm{~cm} \times 100 \mathrm{~cm}$ fiber tub, which is filled with 6,000 liters of water and sand substrate. The tiger shrimp density was 30 shrimps $/ \mathrm{m} 2$ and the tiger shrimp weighed between 0.2 and 0.5 grams. The tiger shrimp was fed commercial shrimp feed of 
which protein substance is between 30 and $42 \%$ three times a day. The water parameter test was conducted in Faculty of Fisheries and Marine Science, Diponegoro University laboratory.

Furthermore, this study used three types of seaweed, namely Sargassum sp, Gracilaria $\mathrm{sp}$, Caulerpa sp and the control. Each treatment was repeated three times.

Water parameter consists of total organic matter, sediment organic substance and ammonia. The analysis method was APHA et al, 1998. Seaweed and tiger shrimp parameters are biomass production, Specific Growth rate (SGR) and tiger shrimp Survival Rate (SR). Effendi (2001)'s formula was adapted to measure Specific Growth rate (SGR) and Survival Rate (SR) of the tiger shrimp.

$$
\mathrm{SGR}=\frac{\ln \mathrm{Wt}-\ln \mathrm{Wo}_{0}}{\mathrm{t}} \times 100 \%
$$

Where:

Wt: Tiger shrimp weight at the end of the study (gram);

Wo: Tiger shrimp waste at the beginning of the study (gram);

t: time.

$$
\mathrm{SR}=\frac{N t}{N o} \times 100 \%
$$

Where:

$\mathrm{Nt}$ : number of tiger shrimp at the end of the study (shrimp);

No: number of tiger shrimp at the beginning of the study (shrimp).

SPSS version 17 was the software used to analyze data on biomass, tiger shrimp and seaweed SGR, tiger shrimp SR and organic substance. One-way Analisis of Variance (ANOVA) was used to evaluate interaction between the treatments and parameter; when it resulted in difference, the researchers proceeded to Duncan Multiple Range Test (DMRT).

\section{RESULTS AND DISCUSSION}

Figure 1 showed amount of organic substance, ammonia $\left(\mathrm{NH}_{3}\right)$ and nitrite $\left(\mathrm{NO}_{2}\right)$ in the shrimp farm for 68 consecutive days with different kinds of seaweed. The organic substance concentration was significant $(p<0.05)$ between treatments.
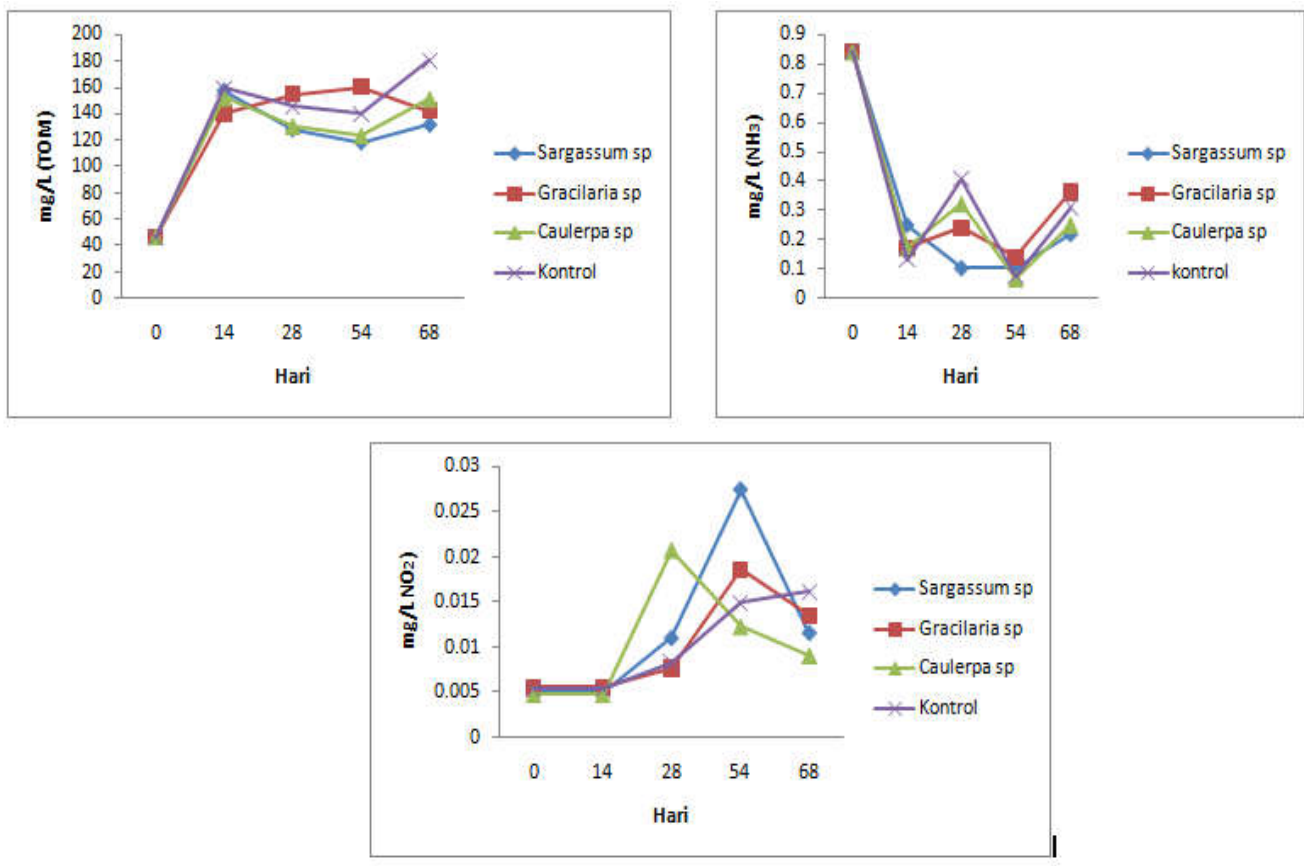

Figure 1 - Total Organic Matter (TOM), Ammonia $\left(\mathrm{NH}_{3}\right)$ and Nitrite $\left(\mathrm{NO}_{2}\right)$ 
Based on Duncan multiple range test, the treatment with Sargassum sp resulted in the lowest concentration of organic substance. The amount of organic substance was between 46.74 and $191.88 \mathrm{mg} / \mathrm{L}$. Ammonia $\left(\mathrm{NH}_{3}\right)$ and nitrite $\left(\mathrm{NO}_{2}\right)$ concentration were not significant $(p>0.05)$ between the treatments. The amount of ammonia and nitrite $\left(\mathrm{NO}_{2}\right)$ was $0.002-0.839$ $\mathrm{mg} / \mathrm{L}$, and $0.0034-0.839 \mathrm{mg} / \mathrm{L}$ consecutively. The amount of ammonia and nitrite was high at the beginning of the study.

Table 1 showed some parameters showing quality of water in the tiger shrimp, for example temperature, dissolved oxygen, salinity and $\mathrm{pH}$.

Table 1 - Quality of Water in the Tiger Shrimp

\begin{tabular}{ll}
\hline Water Parameter & Average \\
\hline Temperature $\left({ }^{\circ} \mathrm{C}\right)$ & $29.4-33.8$ \\
Dissolved oxygen $(\mathrm{mg} / \mathrm{L})$ & $3.4-6.87$ \\
Salinity & $29-38$ \\
$\mathrm{pH}$ & $8.46-9.55$ \\
\hline
\end{tabular}

Tiger Shrimp Production. Table 2 showed production of tiger shrimp. One way ANOVA showed that there was no significant difference between the variables in all of the treatments $(p>0.05)$. The overall biomass of the tiger shrimp was $289-323.2$ grams. The Specific Growth Rate (SGR) and Survival Rate (SR) of the tiger shrimp were 3.35-3.61\% and $83-92 \%$ consecutively.

Table 2 - Production of Tiger Shrimp

\begin{tabular}{cccc}
\hline Treatment & Biomass $(\mathrm{g})$ & SGR $(\%)$ & SR $(\%)$ \\
\hline Sargassumsp & $289 \pm 10.76$ & $3.35 \pm 0.21$ & $83 \pm 8.88$ \\
Gracilaria sp & $321.5 \pm 10.86$ & $3.35 \pm 0.16$ & $87 \pm 6.80$ \\
Caulerpa sp & $320.5 \pm 10.02$ & $3.61 \pm 0.32$ & $92 \pm 3.46$ \\
No seaweed & $323.2 \pm 19.64$ & $3.59 \pm 0.33$ & $89 \pm 9.07$ \\
\hline
\end{tabular}

Seaweed Production. Table 3 showed growth of Sargassum sp, Gracilaria sp and Caulerpa sp seaweed in the semi-intensive tiger shrimp cultivation for 68 consecutive days. The one way ANOVA described significant difference in biomass and SGR of the seaweed $(p<0,05)$. DMRT showed that the biomass and SGR of Caulerpa are the highest of all of the treatments.

Table 3 - Seaweed Production

\begin{tabular}{lll}
\hline Treatment & Biomass $(\mathrm{g})$ & SGR $(\%)$ \\
\hline Sargassum sp & $236.6 \pm 16.81$ & $0.62 \pm 0.29$ \\
Gracilaria sp & $326.2 \pm 13.6$ & $1.11 \pm 0.18$ \\
Caulerpa sp & $385.8 \pm 9.37$ & $1.36 \pm 0.1$ \\
\hline
\end{tabular}

The objective of this study is to analyze ability of seaweed in reducing organic substance in the semi-intensive tiger shrimp cultivation using three types of seaweed (Sargassum sp, Gracilaria sp and Caulerpa sp) while comparing the result with no seaweed treatment. The treatment with seaweed has influence towards the total organic matter (TOM) compared one with no seaweed. Seaweed that can absorb organic substance and thus, reducing percentage of organic materials harmful for tiger shrimp (Rahmaningsih, 2012). Sargassum $\mathrm{sp}$ is the type of seaweed that can reduce the organic substance the most (119.8 $\mathrm{mg} / \mathrm{L}$ ). As an addition, Sargassum is suitable for poly-culture seaweed cultivation. Sargassumhenslowianum can absorb heavy metals and accumulates nutrient biocumulation in the aquaculture in Shenzhen, South China Sea (Yu, et.al, 2014). In this study, the TOM concentration is high due to increasing dosage of shrimp feed, age and weight. On the $14^{\text {th }}$ day, the TOM concentration increased but it declined on the 28th day. However, the TOM concentration goes back up until the 68th day. The analysis reported that the TOM concentration in the tiger shrimp cultivation is $<90 \mathrm{mg} / \mathrm{L}$ (KKP, 2016). Seaweed can inhibit accumulation of the organic material more effectively than the treatment without seaweed. 
The average concentration of ammonia is between 0.304 and $0.352 \mathrm{mg} / \mathrm{L}$, while that of nitrite ranges is between 0.176 and $0.179 \mathrm{mg} / \mathrm{L}$. It happened due to high ammonia content in the water (tiger shrimp cultivation. Furthermore, the concentration of ammonia $(\mathrm{NH} 3)$ and nitrite in the tiger shrimp cultivation is $<0.1 \mathrm{mg} / \mathrm{L}$ and $<1 \mathrm{mg} / \mathrm{L}(\mathrm{KKP}, 2016)$.

There is no difference between biomass, Specific Growth Rate (SGR) and Survival Rate (SR) of $P$. monodon tiger shrimp in the treatment with seaweed and those of $P$. monodon tiger shrimp in the treatment without seaweed. In general, individual weight of the tiger shrimp at the end of the treatment was considered low $(0.62-1.36 \mathrm{grams} / \mathrm{shrimp})$. Several factors, such as high salinity, inhibit optimum growth of the tiger shrimp. Despite being euryhalin, maximum salinity tolerance for tiger shrimp growth is between 15 and $25 \mathrm{ppt}$ (Gunarto, et.al, 2006); salinity during the treatment was twice of the maximum tolerance (between 28-39 ppt). There is significant difference in seaweed production during the treatment $(p<0.05)$. Seaweed is able to accumulate and absorb organic substance and more importantly use the substance as nutrients (Saputra, et.al, 2017). Caulerpa has higher average production compated to Sargassum and Gracilaria. Each type of seaweed has different growth rate depend on some factors, such as environment and physiology of the seaweed.

\section{CONCLUSION}

Based on the finding, Sargassum sp and Caulerpa sp have positive influence towards decline of organic substance. On the other hand, ammonia $\left(\mathrm{NH}_{3}\right)$, nitrite $\left(\mathrm{NO}_{2}\right)$, biomass and shrimp SGR do not have any influence towards the decline. Biomass and SGR of the seaweed are different in which average biomass and SGR of Caulerpa seaweed are 128.6 grams and 1,363 grams consecutively. The implication is that poly-culture is the most suitable aquaculture system for both seaweed and tiger shrimp.

\section{ACKNOWLEDGMENTS}

The authors would like to thank Coastal Resource Management Study Program, Aqua Culture Department for their support upon completion of this study.

\section{REFERENCES}

1. APHA, AWWA, WPCF (1998) Standard methods for the examination of water and wastewater, American Public Health Association, American Water Works Association, $20^{\text {th }}$ ed, Water Pollution Control Federation: Washington, DC, pp 2-24-4-159

2. Buschmann, A, H. 1996. An introduction to ilntegrated farming and the use of seaweeds as biofilters. Hydrobiologia 326 (327): 59-60

3. Chaitanawistuti, N., W, Santhaweesuk., S, Kritsanapuntu. 2011. Performance of the seawees Gracilaria salicornia and Caulerpa lentillifera as biofilters in a hatchery scale recirculating aquaculture system for juvenile spotted babylons (Babylinia areolata). Aquaculture Int 19: 1139-1150.

4. Chow, F, Y., Macchivello, J., Santa, Cruz, S., Fonck, E. 2001. Utilization of Gracilaria chilensis (Rhodophyta: Gracilariaceaea) as a biofilter in the depuration of effluents from tank culture of fish, oysters and sea urchin. Journal World Aquacul Soc. 32: 215-219

5. Effendi, M. I. 2001. Biologi Perikanan. Yayasan Pustaka Nusantara. Yogyakarta 163 hal

6. Gunarto., M., \& Atmomarsono, M. 2006. Tiger Shrimp (Penaues monodon) Growth at Different Stocking Denities in High Salinity Pond Using Mangrove Reservoir. Inodnesian Aquaculture Journal, Vol. 1: 1-7

7. Hernandez, I., J, F, Martinez-Aragon., A, Tovar., J, L, Perez-Illorens., J, J Vegara. 2002. Biofiltering efficiency in removal dissolved nutrients by three species of estuarine macroalgae cultivated with sea bass (Dicentrarchus labrax) waste waters 2 Ammonia, Journal App Phycol 14: 375-384. 
8. Kementrian Kelautan dan Perikanan. 2016. Peraturan Menteri Kelautan dan Perikanan Republik Indonesia No. 75/PERMEN-KP/2016 Tentang: Pedoman umum pembesaran udang windu (Penaeus monodon) dan udang vaname (Litopnaes vannamei). Jakarta. Kementrian Kelautan dan Perikanan Republik Indonesia.

9. Kovitadhi, S., U, Kovitadhi., P, Sawangwong., J, Maechado. 2008. A laboratory scale recirculating aquaculture system for juveniles of freshwater pearl mussel Hyriopsis (Limnoscapha) Myersiana (Lea, 1856). Aquaculture 275: 169-177.

10. Li, Yilin., C, E, Boyd. 2016. Laboratory Tests of Bacterial Amendments fo Accelerating Oxidation Rate of Amonia, Nitrite and Organic Matter in Aquaculture Pond Water. Aquaculture 460 (2016): 45-58

11. Martenez-Aragon, J, F., Hernandez, I., J, L, Perez-llorens., R, Vazquez., J, J, Vergara. 2002. Biofiltering efficiency in removal dissolved nutrients by three species of estuarine macroalgae cultivated with sea bass (Dicentrarchus labrax) waste wate 1 phosphate. Journal App Phycol 14: 365-374.

12. Msuya, F, E., M, S, Kyewalyanga., D, Salum. 2006. The Performance of the seaweed Ulva reticulate as a biofilter in a low-tech, low cost, gravity generated water flow regime in Zanzibar, Tanzania, Aquaculture 254: 284-292.

13. Neori, A. et al. 1996. Seaweed biofilters as regulators of water quality in integrated fish seaweed culture unit. Aquaculture 141: 183-199.

14. Rahmaningsih, S. 2012. Application of Seaweed as a Natural Biofilter Pond Water to Reduce the Level of Disease on Vannamei Shrimp. Jurnal Teknologi Perikanan dan Kelautan. 3:11-16

15. Saputra, N, R., Sukoso., H, Kartikaningsih. 2017. A solid waste water pond tiger shrimp (Penaeus monodon) as Fertilizer for Caulerpa lentillifera. J Exp Life Sci. Vol 7 (1): 17-21

16. Wulandari, T., Widyorrini, N., Purnomo, P. W. 2015. Hubungan Pengelolan Kualitas Air Dengan Kandungan Bahan Organik, NO2 dan NH3 Pada Budidaya Udang Vannamei (Litopenaeus vannamei) Di Desa Keburuhan Purworejo. Journal of Management of Aquatic Resources, 4: 42-48.

17. Yu, Zonghe., X, Zhu., Y, Jiang., P, Luo., C, Hu. 2014. Bioremediation and fodder potentials of two Sargassum spp, in coastal waters of Shenzhen, South Cina. Marine Pollution Bulletin 85: 797-802. 